\title{
Knowledge and Attitude towards Ageing among Health Science University Students
}

\author{
Devinder Kaur Ajit Singh, Ponnusamy Subramaniam, Nor Najwatul Akmal Ab. Rahman, \\ Fatima Zahra Rusly, Shazli Ezzat Ghazali
}

\section{ABSTRACT}

BACKGROUND: Health Science graduates are increasingly in demand for improving and providing life services among the ageing population. Having substantial knowledge and positive attitude towards ageing will be a key step towards better care giving. However, to date there is limited published literature regarding knowledge and attitude towards ageing among health science students in Malaysia. The objective of our study was to assess knowledge and attitudes towards ageing among health science students.

METHODOLOGY: A total of 786 (120 male, 666 female) health science undergraduates participated in this study. This cross-sectional study was conducted using Palmore's Facts on Aging Quiz I (FAQ I) and Kogan's Attitudes towards Older People (KAOP) to assess knowledge of ageing and attitudes towards older adults respectively.

RESULTS: Majority of students in clinical $(69.6 \%)$ and non-clinical programmes $(65.6 \%)$ showed moderate knowledge towards ageing. More than two-third of students in clinical $(77.2 \%)$ and non-clinical programs $(\mathbf{7 5 . 8 \% )}$ demonstrated a slightly positive attitude towards ageing. A significant moderate positive correlation ( $r=.308, p<0.05)$ was found between knowledge of ageing and attitudes towards older adults. Clinical type of programme $(t=-1.97, p<0.05)$ and Malay ethnicity $(t=2.37, p<0.001)$ were significant factors that influenced both knowledge and attitudes towards ageing.

CONCLUSION: Health science students demonstrated a moderate knowledge and positive attitude towards ageing. Refining the current geriatric care curriculum with integration of experiential learning may further enhance knowledge and attitude towards ageing in health science students.

KEYWORDS: Attitudes, Beliefs, Knowledge, Older adults, Undergraduates

This article may be cited as: Singh DKA, Subramaniam P, NNAA, Rusly FZ, Ghazali SE. Knowledge and Attitude towards Ageing among Health Science University Students. J Liaquat Uni Med Health Sci. 2018;17(01):36-41. doi: 10.22442/jlumhs.181710546

\section{INTRODUCTION}

The number of older adults has increased in the past few decades globally ${ }^{1}$. It is estimated that approximately $28 \%$ and $21 \%$ of Western Europe's and US population will be aged above 65 years old by the year 2030 respectively $^{2}$. A similar pattern is seen in Malaysia, ${ }^{3}$ where a person aged 60 and above is considered an older adult ${ }^{4,5}$.

Requirements for skilful and experienced health care providers are of the utmost importance ${ }^{6}$. All health science students will at one time or another interacts and treats older adults upon graduation. Some of the prerequisites of effective care in any specialised discipline including geriatric care are interest, positive attitude, knowledge and skills ${ }^{7}$. However, literature showed that undergraduates from health science courses often lack these requirements to provide best possible care in the management of older adults ${ }^{1,8-11}$.
Lack of knowledge regarding geriatric care has been reported among nursing and medical undergraduates $^{8,9}$. It has also been demonstrated that there is a positive association between knowledge about care of older adults and attitudes towards ageing ${ }^{10}$. Studies to date have shown contradictory results with positive ${ }^{12-}$ ${ }^{14}$ and negative attitudes towards older adults ${ }^{15}$.

However, there is no information regarding knowledge and attitude towards ageing amongst Malaysian health science students. Cultural values, norms and social structures of a community appeared to influence the attitudes of undergraduates towards older adults ${ }^{9,10,16}$. We aimed to assess level of knowledge and attitude towards older adults and its association among clinical and non-clinical health science undergraduates.

\section{METHODOLOGY}

Health science students were invited to participate in 
this cross-sectional study using purposive sampling. Written information regarding this study was distributed among health science students via the programmes at the Faculty of Health Sciences, Universiti Kebangsaan Malaysia. Informed written consent was obtained from all participants.

Nine hundred and eight students participated in the research and were given the questionnaires to be filled. However, only 786 students completed and returned the questionnaires. Participants were categorised under clinical and non-clinical based programmes based on courses they were enrolled in Clinical based programmes included Physiotherapy, Occupational therapy, Speech therapy, Audiology, Dietetics, Diagnostic Imaging and Radiotherapy and Optometry. Whilst, the non-clinical based programmes were Nutritional sciences, Bio-medical sciences and Environmental health and Industrial training. All participants were Malaysian and had completed the sociodemographic questionnaire.

Knowledge and attitude towards ageing were measured using Fact's on Aging Quiz I (FAQ I) and Kogan's Attitude towards Older People (KAOP) respectively ${ }^{16,17}$. FAQ I consists of 25 true/false statements regarding basic physical, mental and social facts about ageing and the most regular misinterpretations about ageing ${ }^{16}$. Questions answered correctly were marked as one point and zero for wrong or no answer ${ }^{8}$. The score ranged between 0 to 25, with higher total scores indicating greater knowledge regarding ageing ${ }^{16}$. KAOP comprises of 34 items, in which, 17 items each express negative and positive statements about older adults. Its answers have a six-point response likert scale, from one (strongly disagree) to six (strongly agree $)^{17}$. Scores on the negatively worded items are reversed to obtain the total score ${ }^{17}$. The total score range from 34 to 204, with a higher total score reflecting a more positive attitude ${ }^{17}$. Data was analysed using Statistical Products and Service Solution (SPSS, Version 22.0, IBM Corp., Armonk, New York.).

The midpoint number 3.5 was used to replace the missing data on a KAOP questionnaire as suggested by Pallant et $\mathrm{al}^{18}$. The demographic data, total score of FAQ I and KAOP were reported descriptively. The correlation between FAQ I and KAOP score was assessed using Pearson's correlation. The results were analysed within $95 \%$ confidence interval, and $p<$ 0.05 was considered statistically significant. Hierarchical multiple regression analysis was performed to determine the factors that influenced FAQ I and KAOP amongst the undergraduates. This study was approved by the Research Ethic Committee at the University (UKM1.5.3.5./244/JEP-2016-040).

\section{RESULTS}

The demographic data is as in Table I. A total of 786 undergraduates ( $86 \%$ response rate), were involved in this study and data was categorized into clinical and non-clinical based programs. Approximately $59 \%$ of the students were enrolled in clinical based programs. Majority of the students (85\%) were females and aged between 20-25 years old. Most of the students $(67.9 \%)$ had a moderate level of knowledge on ageing. About a one fifth (22\%) of them had negative attitudes towards older adults.

Figure I shows the correlation between knowledge and attitude of ageing. There was a moderate positive correlation $\left(0.308^{* *}, p<0.001\right)$ between knowledge and attitude towards ageing.

Table II shows the influence of the independent variables on knowledge of ageing and attitudes towards older adults. Type of programme and ethnicity had significant $(p<0.05)$ influence on knowledge and attitudes of ageing.

FIGURE I:

CORRELATION BETWEEN KNOWLEDGE (FAQ I) AND ATTITUDES (KAOP)

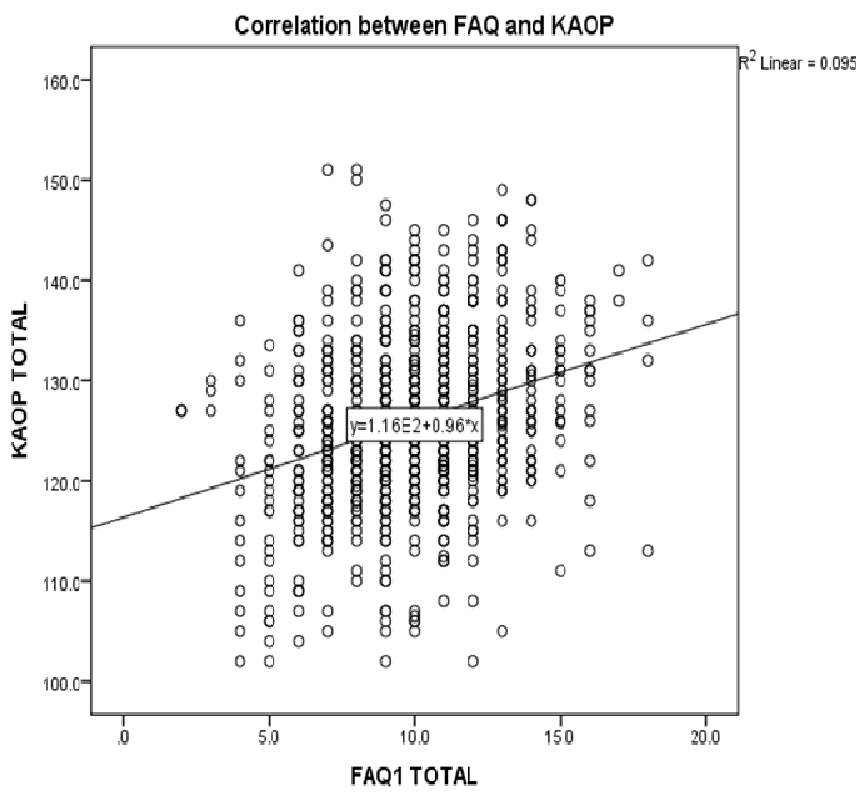


Devinder Kaur Ajit Singh, Ponnusamy Subramaniam, Nor Najwatul Akmal Ab. Rahman, Fatima Zahra Rusly, Shazli Ezzat Ghazali

TABLE I: SUMMARY OF PARTICIPANTS' SOCIO-DEMOGRAPHIC INFORMATION

\begin{tabular}{|c|c|c|c|c|}
\hline Variable & $\begin{array}{l}\text { Clinical based } \\
\text { programs } \\
(n=460)\end{array}$ & $\begin{array}{l}\text { Non-clinical based } \\
\text { programs }(n=326)\end{array}$ & $\begin{array}{c}\text { Total } \\
(\mathrm{N}=786)\end{array}$ & $\begin{array}{l}\text { Significance } \\
\text { level } \\
\text { (p) }\end{array}$ \\
\hline $\begin{array}{l}\text { Gender, n (\%) } \\
\text { Males } \\
\text { Females }\end{array}$ & $\begin{array}{c}69(15.0) \\
391(85.0)\end{array}$ & $\begin{array}{c}51(15.6) \\
275(84.4)\end{array}$ & $\begin{array}{l}120(15.3) \\
666(84.7)\end{array}$ & $0.805^{\mathrm{b}}$ \\
\hline $\begin{array}{l}\text { Participants based on year of study, } \mathrm{n}(\%) \\
1^{\text {st }} \text { year } \\
2^{\text {nd }} \text { year } \\
3^{\text {rd }} \text { year } \\
4^{\text {th }} \text { year }\end{array}$ & $\begin{array}{l}120(26.1) \\
140(30.4) \\
128(27.8) \\
72(15.7)\end{array}$ & $\begin{array}{l}81(24.8) \\
89(27.3) \\
96(29.4) \\
60(18.4)\end{array}$ & $\begin{array}{l}201(25.6) \\
229(29.1) \\
224(28.5) \\
132(16.8)\end{array}$ & $0.400^{b}$ \\
\hline $\begin{array}{l}\text { Mean Age }(\mathrm{SD}) \text { years } \\
20-25 \text { years old, } n(\%) \\
26-31 \text { years old, } n(\%)\end{array}$ & $\begin{array}{c}- \\
449(97.6) \\
11(2.4)\end{array}$ & $\begin{array}{c}- \\
311(95.4) \\
15(4.6)\end{array}$ & $\begin{array}{c}21.8(1.6) \\
760(96.7) \\
26(3.3) \\
\end{array}$ & $0.880^{b}$ \\
\hline $\begin{array}{l}\text { Religion, } \mathrm{n}(\%) \\
\text { Muslim } \\
\text { Christian } \\
\text { Buddha } \\
\text { Hindu } \\
\text { Others }\end{array}$ & $\begin{array}{c}- \\
291(63.3) \\
30(6.5) \\
124(27.0) \\
13(2.8) \\
2(0.4)\end{array}$ & $\begin{array}{c}- \\
261(80.1) \\
17(5.2) \\
31(9.5) \\
17(5.2) \\
0(0)\end{array}$ & $\begin{array}{c}- \\
552(70.2) \\
47(6.0) \\
155(19.7) \\
30(3.8) \\
2(0.3)\end{array}$ & $<0.001^{b}$ \\
\hline $\begin{array}{l}\text { Ethnic, n(\%) } \\
\text { Malay } \\
\text { Non- Malay } \\
\end{array}$ & $\begin{array}{c}- \\
291(63.3) \\
173(37.6) \\
\end{array}$ & $\begin{array}{c}- \\
255(78.2) \\
71(21.8) \\
\end{array}$ & $\begin{array}{c}- \\
546(69.5) \\
240(30.5) \\
\end{array}$ & $<0.001^{b}$ \\
\hline $\begin{array}{l}\text { Work experience, } \mathrm{n}(\%) \\
\text { No } \\
\text { Yes }\end{array}$ & $\begin{array}{c}- \\
447(97.2) \\
13(2.8) \\
\end{array}$ & $\begin{array}{c}- \\
299(91.7) \\
27(8.3)\end{array}$ & $\begin{array}{c}- \\
746(94.9) \\
40(5.1)\end{array}$ & $0.001^{b}$ \\
\hline $\begin{array}{l}\text { History of taking care an older adult } \\
\text { (Previous/current), } \mathrm{n}(\%) \\
\text { Yes } \\
\text { No } \\
\text { Not sure }\end{array}$ & $\begin{array}{c}291(63.3) \\
145(31.5) \\
24(5.2) \\
\end{array}$ & $\begin{array}{l}205(62.9) \\
97(29.8) \\
24(7.4) \\
\end{array}$ & $\begin{array}{c}496(63.1) \\
242(30.8) \\
48(6.1) \\
\end{array}$ & $0.914^{b}$ \\
\hline FAQ 1 mean(SD)/(Range) & $\begin{array}{c}10.1(2.8) / \\
(3-18)\end{array}$ & $\begin{array}{l}9.6(2.8) / \\
(2-17) \\
\end{array}$ & $\begin{array}{c}10.1(2.8) / \\
(2-18)\end{array}$ & $0.049^{\mathrm{a}}$ \\
\hline $\begin{array}{ll}\text { FAQ I score; } \\
\begin{array}{cl}\text { Low } & (0-8), \mathrm{n}(\%) \\
\text { Moderate } & (9-17), \mathrm{n}(\%) \\
\text { High } & (18-25), \mathrm{n}(\%)\end{array}\end{array}$ & $\begin{array}{c}- \\
136(29.6) \\
320(69.6) \\
4(0.9)\end{array}$ & $\begin{array}{c}- \\
112(34.4) \\
214(65.6) \\
0(0)\end{array}$ & $\begin{array}{c}- \\
248(31.6) \\
534(67.9) \\
4(0.5)\end{array}$ & $<0.001^{b}$ \\
\hline KAOP mean(SD)/ (Range) & $\begin{array}{l}126.4(8.8) / \\
(102-151)\end{array}$ & $\begin{array}{l}125.17(8.7) / \\
(102-151)\end{array}$ & $\begin{array}{l}125.9(8.9) / \\
(102-151)\end{array}$ & $0.013^{\mathrm{a}}$ \\
\hline $\begin{array}{lc}\text { KAOP score; } & \\
\text { Very negative } & (3-62.3), \mathrm{n}(\%) \\
\text { Negative } & (62.4-90.7), \mathrm{n}(\%) \\
\text { Slightly negative } & (90.8-119.1), \mathrm{n}(\%) \\
\text { Slightly positive } & (119.2-147.5), \mathrm{n}(\%) \\
\text { Positive } & (147.6-175.9), \mathrm{n}(\%) \\
\text { Very positive } & (176-204), \mathrm{n}(\%)\end{array}$ & $\begin{array}{c}0(0) \\
0(0) \\
96(20.9) \\
355(77.2) \\
9(2.0) \\
0(0)\end{array}$ & $\begin{array}{c}0(0) \\
0(0) \\
77(23.6) \\
247(75.8) \\
2(0.6) \\
0(0)\end{array}$ & $\begin{array}{c}0(0) \\
0(0) \\
173(22.0) \\
602(76.6) \\
11(1.4) \\
0(0)\end{array}$ & $<0.001^{b}$ \\
\hline
\end{tabular}

FAQ I score: categorized based on the study by Bleijenberg et al., (2012) ${ }^{10}$

KAOP score :categorized based on the study by Doherty et al., (2011)

${ }^{a}$ Independent Samples $t$-test, ${ }^{b}$ Chi Square test 
Knowledge and Attitude towards Ageing among Health Science University Students

TABLE II: FACTORS INFLUENCING KNOWLEDGE OF AGEING (FAQ 1) AND ATTITUDES TOWARDS OLDER ADULTS (KAOP) AMONG HEALTH SCIENCE STUDENTS

\begin{tabular}{|c|c|c|c|c|c|c|c|c|}
\hline & \multicolumn{4}{|c|}{ FAQ I } & \multicolumn{4}{|c|}{ KAOP } \\
\hline & B & $\mathrm{t}$ & $p$ & $95 \% \mathrm{Cl}$ & B & $\mathrm{t}$ & $p$ & $95 \% \mathrm{Cl}$ \\
\hline \multirow{2}{*}{ Programme* $^{*}$} & \multicolumn{8}{|c|}{ Reference group: clinical based programme } \\
\hline & -.502 & -2.485 & .013 & $-.898 ;-.105$ & -1.245 & -1.972 & .049 & $-2.485 ;-.005$ \\
\hline \multirow{2}{*}{$\begin{array}{l}\text { Races* } \\
\text { Non-malay }\end{array}$} & \multicolumn{8}{|c|}{ Reference group: Malay } \\
\hline & .492 & 2.256 & .024 & $.064 ; .921$ & 2.366 & 3.481 & .001 & $1.032 ; 3.700$ \\
\hline \multirow{2}{*}{$\begin{array}{l}\text { Year of study } \\
1^{\text {st }} \text { year } \\
2^{\text {nd }} \text { year } \\
3^{\text {rd }} \text { year }\end{array}$} & \multicolumn{8}{|c|}{ Reference group: $4^{\text {th }}$ year } \\
\hline & $\begin{array}{l}.438 \\
-.304 \\
.585\end{array}$ & \begin{tabular}{|l|}
1.414 \\
-1.005 \\
1.930 \\
\end{tabular} & $\begin{array}{l}.158 \\
.315 \\
.054 \\
\end{array}$ & $\begin{array}{l}-.170 ; 1.046 \\
-.899 ; .290 \\
-.010 ; 1.180\end{array}$ & \begin{tabular}{|l|}
1.148 \\
.321 \\
1.456 \\
\end{tabular} & \begin{tabular}{|l|}
1.183 \\
.338 \\
1.532 \\
\end{tabular} & $\begin{array}{l}.237 \\
.735 \\
.126 \\
\end{array}$ & $\begin{array}{l}-.758 ; 3.054 \\
-1.543 ; 2.185 \\
-.410 ; 3.322\end{array}$ \\
\hline \multirow{2}{*}{$\begin{array}{l}\text { Previous taking care of } \\
\text { older adults }\end{array}$} & \multicolumn{8}{|c|}{ Reference group: yes } \\
\hline & .267 & 1.302 & .193 & $-.135 ; .668$ & .835 & 1.301 & .194 & $-.425 ; 2.095$ \\
\hline Total $R^{2}$ & \multicolumn{4}{|c|}{0.34} & \multicolumn{4}{|c|}{.027} \\
\hline
\end{tabular}

Note: $\left({ }^{*}\right) p<0.05$

\section{DISCUSSION}

We aimed to assess the level and association between knowledge and attitude towards ageing among Malaysian health science students in this study. The results showed that majority of the students had moderate knowledge and slightly positive attitudes toward ageing regardless of the program type. There was a positive moderate correlation between knowledge and attitudes towards ageing. Type of health science programs and ethnicity were found to influence both knowledge and attitudes towards ageing among health science students in our study.

About three quarter of the health science students had moderate levels of knowledge about ageing, a finding in agreement to other studies that also reported moderate levels of knowledge related to ageing among final year undergraduates ${ }^{9,10,13}$. Most of the previous studies indicated that senior students had higher level of knowledge about ageing compared to the fresh one ${ }^{10,13,20}$, However, this comparison was not the objective of our present study.

Overall, health science students had positive attitudes towards older adults. Positive attitudes among the students in the present study may be as a result of social and cultural perspectives of the population in Asian countries. The multicultural society of Malaysia hold similar values, cultural and religious norms towards older adults $8,12,14$. However, in the present study, students were found to have lower mean score of KAOP when compared with previous studies ${ }^{7,14,21}$. One of the reasons for this could be due to the fact that our study results include both clinical and non-clinical based health science students. A disparity may exist in the current geriatric curriculum within the programs.

A significant positive correlation existed between knowledge of ageing and attitudes towards older adults. This indicates that students with higher knowledge about ageing, may possess more positive attitudes towards older adults or vice versa. This finding is consistent with results from previous studies $^{8,13,22,23}$. A positive impact on students' attitude has been shown with improved training in geriatric care and exposure to older adults ${ }^{24}$. Moreover, students' knowledge of ageing was greater in those who had taken geriatric modules or courses $^{25,26}$. Similarly, health science students possessed more positive attitudes with geriatric related education ${ }^{11,14,29}$. Clinical hands-on training was also shown to improve knowledge and attitudes towards older adults with severe mental conditions ${ }^{30}$.

Malay ethnicity and clinical based programmes had an influence on knowledge of ageing and attitude towards older adults. Students' attitudes were affected by cultural values and experience of dealing with older adults in another similar study ${ }^{27}$. The oriental traditional customs of respecting older adults are practiced since childhood in many Asian societies. Compared to Malays, extended family systems are also predominantly practiced in non-Malay societies such as Chinese and Indians. For example, Chinese nursing undergraduates were found to have more positive attitudes towards older adults compared to 
Australian nursing undergraduates ${ }^{28}$.

A limitation of this study is that the participants were limited to health science students at a public university. Thus, the results obtained may not be generalized to other university students. Another limitation was that there was difficulty comparing directly due to non-homogenous number of students between the programs. Future studies are required to assess and compare knowledge of and attitudes towards ageing of health science students from different universities. It will also be interesting to do a follow up study, of cohort students of the same programme from first to fourth year of study.

\section{CONCLUSION}

In conclusion, this study demonstrated that health science students have moderate knowledge of ageing and hold a positive attitude towards older adults. A significant correlation existed between knowledge of ageing and attitude towards older adults. It is important to improve attitudes towards ageing and knowledge about ageing in health science students to enhance geriatric health care. Including ageriatric care module based on the need of the community in the present curriculum, interactive educational programs between health science students and older adults may be helpful. Clinical attachment at geriatric wards or institutions may also be important to enhance health science students' knowledge regarding ageing and promoting positive attitudes towards ageing for best future geriatric care.

\section{ACKNOWLEDGMENT}

We would like to thank all health science students at Faculty of Health Sciences, Universiti Kebangsaan Malaysia for their participation in this study. We would also like to thank Mr. Indarpal Singh, Didar Singh, who assisted in the proof reading and English language editing of this manuscript.

\section{REFERENCES}

1. Gonçalves DC, Guedes J, Fonseca AM, Pinto FC, Martin I, Byrne GJ, et al. Attitudes, knowledge, and interest: preparing university students to work in an aging world. Int Psychogeriatr. 2011; 23 (2):315-21.doi: 10.1017/S1041610210001638.

2. Kinsella K, He W. U.S Census Bureau. International Population Reports, P95/09 -1. An Aging World: 2008. Washington, DC:U.S. Government Printing Office, 2009. Available from: http://www.Census.gov/prod/2009pubs/p95-1.pdf.

3. Wan-Ibrahim WA, Zainab I. Some demographic aspects of population aging in Malaysia. World Appl. Sci. J. 2014; 30(7):891-894. doi: 10.5829 / idosi.wasj.2014. 30. 07. 14078.
4. World Health Organisation. Health of the Elderly Report World Health Organization 1989. Technical Report Series No.779. Geneva, World Health Organisation, 1989. Available from: http:// apps.who.int / iris/ bitstream/10665/39521/1/ WHO_TRS_779.pdf.

5. World Health Organisation. The health of older people in selected countries of the Western Pacific Region, 2014. Available from: http:// iris.wpro.who.int/handle/10665.1/10516.

6. Palmore EB, Branch L, Harris D. Encyclopedia of Ageism. $1^{\text {st }}$ ed. New York: The Howarth Reference Press, 2005. Available from: http://library. mpib-berlin.mpg.de/toc/ze_2006_255.pdf

7. Erdemir F, Kav S, Citak EA, Hanoglu Z, Karahan A. A Turkish version of Kogan's attitude toward older people (KAOP) scale: reliability and validity assessment. Arch GerontolGeriatr. 2011; 52 (3):e162-5.doi: 10.1016/j.archger.2010.10.019

8. Eltantawy SAE. Relation between nursing students' knowledge of aging and attitude towards elderly people and their will and intent to work with the elderly. J Edu Pract. 2013; 4(27):125-137.

9. Liu Z, Pu L, Wang H, Hu X. Survey of attitude towards and understanding of the elderly amongst Chinese undergraduate medical students. Asian Biomed. 2014; 8(5):615 - 22. doi: 10.5372/19057415.0805.335.

10. Bleinjenberg $N$, Jansen MJM, Schuurmans MJ. Dutch nursing students' knowledge and attitudes towards older people - A longitudinal cohort study. J. Nurs. Educ. Pract. 2012; 2(2):1-8. Doi. 10.5430/jnep.v2n2p1.

11. Kaempfer D, Wellman NS, Himburg SP. Dietetics students' low knowledge, attitudes, and work preferences toward older adults indicate need for improved education about aging. American Dietetic Association. J. Am. Diet. Assoc. 2002; 102(2):197-202.

12. Hweidi IM, Al-Obeisat SM. Jordanian nursing students' attitudes toward the elderly. Nurse Educ. Today. 2006; 26(1):23-30. doi:10.1016/ j.nedt.2005.06.003.

13. Lambrinou $E$, Sourtzi $P$, Kalokerinou $A$, Lemonidou C. Attitudes and knowledge of the Greek nursing students toward older people. Nurse Educ. Today. 2009; 29(6):617-622. doi:10.1016/j.nedt.2009.01.011.

14. Wang CC, Liao WC, Kao MC, Chen YJ, Lee MC, Lee MF, et al. Taiwanese medical and nursing student interest leves in and attitudes toward geriatrics. Annals. Acad. Med. Singapore 2009; 38:230-36.

15. Allan LJ, Johnson JA. Undergraduate attitudes toward the elderly: The role of knowledge, 
contact, and aging anxiety. Edu.Gerontol. 2008; 35:1-14. Doi.10.1080/03601270802299780.

16. Palmore EB. The Facts on Aging Quiz. $2^{\text {nd }}$ ed. New York: Springer, 1998.

17. Kogan N. Attitudes toward old people: the development of a scale and an examination of correlates. J. Abnorm. Soc. Psychol.1961; 64:4454.

18. Pallant J. SPSS Survival Manual: A step by step guide to data analysis using SPSS. $4^{\text {th }}$ ed. Australia: Allen \& Unwin, 2011.

19. Doherty M, Mitchell EA, O'Neill S. Attitudes of healthcare workers towards older people in a rural population: A survey using Kogan scale. Nurs. Res. Pract. 2011; 2011: 352627. doi.10.1155/2011/352627.

20. Panmial PD, Minhat HS, Anita AR. Factors associated with knowledge of ageing among healthcare related students in Universiti Putra Malaysia. Int. J. Public Health Clin. Sci. 2015; 2 (4):75-87.

21. Turan E, Yanardag M, Metintas S. Attitudes of students of health sciences towards the older persons. Nurse Educ Today. 2016; 36:53-57. https://doi.org/ 10.1016/ j.nedt.2015.07.011.

22. Cote R. Basw students' perception of aging and their intention to work with older adults in the future. 2008. Msc. Dissertation. University of North Carolina charlotte. Available from: http:// proquest.umi.com.

23. Milutinovic D, Simin D, Kacavendic J, Turkulov V. Knowledge and attitudes of health care science students toward older people. Med Pregl. 2015;
68:382-86.

24. Sheikh RB, Mathew E, Rafique AM, Suraweera RSC, Khan H, Sreedharan J. Attitude of medical students toward old people in Ajman, United Arab Emirates. Asian J. Gerontol. Geriatr. 2013; 8:85-9.

25. Al senany S. Student nurses' attitude and knowledge towards the care of older people in Saudi Arabia. British Society of Gerontology 2009. 19:1-28

26. Augustine J, Shah A, Makadia N, Shah A, Lee JK. Knowledge and attitudes regarding geriatric care and training among student pharmacists. Currents in Pharm. Teach. Learn. 2014; 6(2):226-232. https://doi.org/10.1016/j.cptl.2013.11.001.

27. Khan NA, Cotter K. Student attitudes about older adults: Caring and cultural assimilation. McNair Scholar J. (California State University, Sacramento)2011; 12:152-177.

28. Bergman YS, Bodner E, Cohen-Fridel S. Cross-cultural ageism: ageism and attitudes toward aging among Jews and Arabs in Israel. Int Psychogeriatr 2013; 25 (1):6-15. doi: 10.1017/S1041610212001548.

29. Hobbs C, Dean CM, Higgs J, Adamson B. Physiotherapy students' attitudes towards and knowledge of older people. Aust. J. Physiother. 2006; 52(2): 115-119.

30. Basri MAFA, Subramaniam $P$, Ghazali SE, Singh DKA. A review of knowledge and attitudes towards dementia among college and university students. J Clin Diagn Res. 2017; 11(11): LEO1 LEO7. doi: 10.7860/JCDR/2017/29739.10865.

AUTHOR AFFILIATION:
Devinder Kaur Ajit Singh
Physiotherapy Programme, Faculty of Health Sciences
Universiti Kebangsaan Malaysia.
Ponnusamy Subramaniam (Corresponding Author)
Health Psychology Programme, Faculty of Health Sciences
Universiti Kebangsaan Malaysia.
Email: ponnusaami@ukm.edu.my
Nor Najwatul Akmal Ab. Rahman
Physiotherapy Programme, Faculty of Health Sciences
Cyberjaya University College of Medical Sciences
Universiti Kebangsaan Malaysia.
Fatima Zahra Rusly
Physiotherapy Programme, Faculty of Health Sciences
Universiti Kebangsaan Malaysia.
Shazli Ezzat Ghazali
Health Psychology Programme, Faculty of Health Sciences
Universiti Kebangsaan Malaysia.

